Article

\title{
Effect of Soil and Foliar Silicon Application on the Reduction of Zinc Toxicity in Wheat
}

\author{
Aleksandra Zajaczkowska ${ }^{\mathbb{D}}$, Jolanta Korzeniowska * ${ }^{\mathbb{D}}$ and Urszula Sienkiewicz-Cholewa \\ Department of Weed Science and Tillage Systems in Wroclaw, Institute of Soil Science and Plant \\ Cultivation-National Research Institute in Pulawy, Orzechowa 61, 50-540 Wroclaw, Poland; \\ a.zajaczkowska@iung.wroclaw.pl (A.Z.); u.sienkiewicz@iung.wroclaw.pl (U.S.-C.) \\ * Correspondence: j.korzeniowska@iung.wroclaw.pl
}

Received: 9 October 2020; Accepted: 2 November 2020; Published: 4 November 2020

check for updates

\begin{abstract}
The aim of the study was to compare soil and foliar application of Si to relieve stress in wheat caused by excess $\mathrm{Zn}$ in the soil. Two pot experiments were carried out in which the soil was contaminated with zinc sulphate at the dose of $600 \mathrm{mg} \mathrm{kg}^{-1} \mathrm{Zn}$ before sowing. Si was applied in the soil in the following doses $200 \mathrm{mg} \mathrm{kg}^{-1}$ and $400 \mathrm{mg} \mathrm{kg}^{-1} \mathrm{Si}$ and as foliar spraying in concentrations $2 \mathrm{mM} \mathrm{L}^{-1}$ and $6 \mathrm{mM} \mathrm{L}^{-1} \mathrm{Si}$ in the form of sodium silicate. The applied dose of $\mathrm{Zn}$ was toxic to wheat and caused a significant decrease in the biomass of shoots and roots. Soil application of Si reduced the negative effect of $\mathrm{Zn}$ on plants and significantly increased the biomass of the tested organs. The foliar application of Si did not reduce the decrease of plant biomass. Soil contamination with Zn caused a drastic increase in $\mathrm{Zn}$ concentration in shoots and roots, while Si applied in the soil significantly decreased this concentration. The increase in soil $\mathrm{pH}$, which was caused by sodium silicate, also affected the decrease in Zn concentration in plants. The plants absorbed Si applied to the soil, which is indicated by an increase in the Si content in shoots compared to the control. In the case of foliar spraying, only a higher dose of $\mathrm{Si}$ increased its concentration in the plants. The application of $\mathrm{Si}$ in the soil, in contrast to foliar application, reduced the transfer of $\mathrm{Zn}$ from roots to shoots. The higher effectiveness of soil application of Si than foliar application in alleviating the toxicity of $\mathrm{Zn}$ was associated with both an increase in $\mathrm{pH}$ and a higher uptake of Si by plants.
\end{abstract}

Keywords: wheat; Zn stress; $\mathrm{Si}$; method of application

\section{Introduction}

Environmental pollution with heavy metals is a consequence of industrial development and urbanisation. The main sources of excess $\mathrm{Zn}$ in the soil are dusts emitted from non-ferrous metal smelters, burnt coal and oil and municipal solid waste [1]. Zn contamination can also come from the metallurgical and paint industries [2]. Zinc contamination of the soil is an environmental problem that occurs all over the world. Most $\mathrm{Zn}$ is mined in China, where soil contamination with this metal often occurs [3]. In Europe, high levels of $\mathrm{Zn}$ in the soil are found in the Canary Islands, central-western Spain, France, northern Italy, Slovenia and Greece [4]. Furthermore, in Poland, although only $1.4 \%$ of soils are contaminated with $\mathrm{Zn}$ [5], some areas with an excess of this element can be found.

$\mathrm{Zn}$ is easily taken up by plants from polluted soils, and its excess in the plant interferes with many metabolic and physiological processes and consequently limits yield [6,7]. Too high Zn content inhibits seed germination, plant growth and root development and causes leaf chlorosis. Recent studies have shown a negative effect of $\mathrm{Zn}$ stress on photosynthesis, chlorophyll content and chloroplast ultrastructure in plants $[8,9]$.

Although Si was not considered an essential element for plants, it has been shown to be beneficial for the healthy growth and development of many plant species, in particular, rice and sugar cane $[10,11]$. 
Several authors believe that in the near future, Si may be considered as an essential element for plants $[12,13]$.

$\mathrm{Si}$ is taken up by the roots of plants in the form of $\mathrm{H}_{4} \mathrm{SiO}_{4}[14]$ and its uptake by leaves is debatable and sometimes questioned. Some authors believe that this element is mostly or even completely taken up by the roots [15,16], while others report a high effectiveness of foliar Si application [17-19].

The beneficial effects of $\mathrm{Si}$ are particularly evident in plants exposed to abiotic and biotic stress $[16,20,21]$. Over the last two decades, many studies have been carried out to clarify the role of $\mathrm{Si}$ in increased tolerance and resistance of plants to stress. World literature reports on the role of $\mathrm{Si}$ in increasing plant tolerance to drought stress [22,23], salinity stress [24,25] and disease stress [26].

Research has also been conducted on the influence of $\mathrm{Si}$ on stress relief caused by excess heavy metals [27]. Many studies concerned Cd [28-33], while fewer $\mathrm{Cr}$ [34,35], As [36,37] or Cu [38,39]. Si was also reported as a $\mathrm{Zn}$ stress reducing factor. The researchers reported that the excess of $\mathrm{Zn}$ in the substrate decreased the yield, whereas the application of $S i$ reduced the decrease in plant biomass $[8,9]$. The excess of $\mathrm{Zn}$ also led to the excessive concentration of $\mathrm{Zn}$ in various plant organs, while the addition of Si significantly reduced $\mathrm{Zn}$ accumulation in plants $[8,40-43]$. Zn decreased the chlorophyll content in leaves, whereas $\mathrm{Si}$ alleviated these changes $[8,9,42]$. Si also mitigated the harmful effect of $\mathrm{Zn}$ on the ultrastructure of chloroplasts [9]. The excess of $\mathrm{Zn}$ led to an increase in the level of MDA in plants, while the application of Si decreased this level [8]. The excess of $\mathrm{Zn}$ in the substrate caused oxidative stress in plants, which changed the activity of antioxidant enzymes, such as SOD, CAT and APX. In this situation, the addition of Si modified the activity of enzymes, which contributed to the reduction of stress $[8,44]$. The application of $\mathrm{Si}$ also led to the immobilization of $\mathrm{Zn}$ in the substrate, thus reducing its toxicity to plants $[40,45]$.

Almost all above-mentioned studies were carried out under hydroponic conditions, where $\mathrm{Zn}$ and $\mathrm{Si}$ were added to the nutrient solution. Studies conducted in water cultures provide precise answers, but do not reflect the conditions under which plants actually grow. In agricultural practice, farmers can apply Si to the soil or on the plant list, which is completely different from nutrient solution in aquatic cultures. Therefore, research with the use of soil instead of the nutrient solution and with the application of $\mathrm{Si}$, which can be used in practice by farmers, are necessary.

The aim of our research was to investigate the effect of soil and foliar application of $\mathrm{Si}$ on reducing Zn stress for young wheat plants growing in pots filled with soil brought from the field.

\section{Materials and Methods}

\subsection{Pot Experiment}

In order to examine the effect of Si fertilisation of wheat on the reduction of stress caused by the $\mathrm{Zn}$ concentration in the soil, two identical pot experiments were carried out in the greenhouse, one in spring (III-V) and one in autumn (IX-X) 2018. In both experiments, pots were filled with $2.3 \mathrm{~kg}$ of the same soil brought from a field located in Jelcz-Laskowice near Wroclaw, Poland. Physical and chemical properties of the soil are presented in Table 1. Winter wheat of Lindbergh (SAATEN-UNION GmbH, Isernhagen, Germany) cultivar was used as a test plant.

Table 1. Properties of soils used in the experiment.

\begin{tabular}{ccccccccc}
\hline $\mathbf{p H}$ & Sand & Silt & Clay & Corg & $\mathbf{P}^{\mathbf{1}}$ & $\mathbf{K}^{\mathbf{1}}$ & $\mathbf{M g}^{2}$ & Zn $^{3}$ \\
\cline { 2 - 9 } KCl & \multicolumn{3}{c}{$\%$} & \multicolumn{5}{c}{ mg kg $^{-\mathbf{1}}$} \\
\hline 6.5 & 70 & 26 & 4 & 0.7 & 150 & 284 & 116 & 33 \\
\hline
\end{tabular}

sand: $2.0-0.05 \mathrm{~mm}$, silt: $0.05-0.002 \mathrm{~mm}$, clay: $<0.002 \mathrm{~mm}$, Corg-organic carbon, ${ }^{1}$ Enger-Rhiem, ${ }^{2}$ Schachtschabel, 3 aqua regia.

In the experiment, the soil was artificially contaminated with $\mathrm{Zn}$ because the aim was to focus on $\mathrm{Zn}$, whereas naturally occurring contamination usually involves several elements at once. Zn was 
added directly to the soil before sowing in the form of $\mathrm{ZnSO}_{4} \cdot 7 \mathrm{H}_{2} \mathrm{O}$. Si was added to the soil before sowing or applied as a triple foliar spray in the form of $\mathrm{Na}_{2} \mathrm{SiO}_{3} \cdot 5 \mathrm{H}_{2} \mathrm{O}$. Six experimental treatments were tested, each in 4 replications:

(1) 0: control without $\mathrm{Zn}$ and $\mathrm{Si}$

(2) Zn: $600 \mathrm{mg} \mathrm{kg}^{-1} \mathrm{Zn}$ applied to the soil

(3) ZnSi1-soil: $600 \mathrm{mg} \mathrm{kg}^{-1} \mathrm{Zn}$ to the soil $+200 \mathrm{mg} \mathrm{kg}^{-1} \mathrm{Si}$ to the soil

(4) ZnSi2-soil: $600 \mathrm{mg} \mathrm{kg}^{-1} \mathrm{Zn}$ to the soil $+400 \mathrm{mg} \mathrm{kg}^{-1} \mathrm{Si}$ to the soil

(5) ZnSi1-foliar: $600 \mathrm{mg} \mathrm{kg}^{-1} \mathrm{Zn}$ to the soil + triple foliar spray with $2 \mathrm{mM} \mathrm{L}^{-1} \mathrm{Si}$

(6) ZnSi2-foliar: $600 \mathrm{mg} \mathrm{kg}^{-1} \mathrm{Zn}$ to the soil + triple foliar spray with $6 \mathrm{mM} \mathrm{L}^{-1} \mathrm{Si}$

First $\mathrm{Zn}$ was added to the soil and then $\mathrm{Si}$ after 3 weeks of incubation, each time carefully mixing the additives with the soil. All the time the soil moisture was kept at the level of $60 \%$ of the field water capacity. Wheat was sown one week after the introduction of Si into the soil. Two weeks after sowing, plant thinning was done down to 25 plants per pot. Si as foliar spray was applied three times at weekly intervals using the SG11 hand sprayer (Andreas Stihl AG \& Co. KG, Waiblingen, Germany). The first application was made a few days after the plant thinning. Plants from each pot were sprayed separately. The solution was applied to completely cover the plants without forming drops on the edge of leaves.

The plants were harvested 2 weeks after the last Si application (60 days after sowing). The aboveground parts of wheat were cut $2 \mathrm{~mm}$ above the ground and rinsed with distilled water. The roots were removed from pots, cleaned from the soil, initially rinsed with tap water and then rinsed for $2 \mathrm{~h}$ with distilled water using a rotary mixer. Aboveground parts and roots were dried for $24 \mathrm{~h}$ at $40^{\circ} \mathrm{C}$, then carefully weighed and finely ground. Soil samples were taken from each pot at the same time as the roots. They were dried at room temperature, ground in a mortar and passed through a sieve with a diameter of $2 \mathrm{~mm}$.

\subsection{Chemical Analysis}

Soil texture was evaluated by the aerometric method [46]; $\mathrm{pH}$ was established potentiometrically in $1 \mathrm{~mol} \mathrm{KCl.dm}{ }^{-3}$ [47]; total organic carbon in soil (TOC) was determined by Tiurin method using potassium dichromate [48]; $\mathrm{P}$ and $\mathrm{K}$ were determined using the Enger-Riehm method $[49,50]$ and $\mathrm{Mg}$ by Schachtschabel method [51]. The total $\mathrm{Zn}$ concentration in the soil was determined using aqua regia. After the digestion, $\mathrm{Zn}$ was determined using the flame atomic absorption spectrometry FAAS (flame atomic absorption spectrometry) method [51]. The available $\mathrm{Zn}$ in the soil was determined by Mehlich 3 method [52-54].

$\mathrm{Zn}$ in shoots and roots was determined by the FAAS method, having first dry ashed the material in a muffle furnace and digested it with 20\% nitric acid [55]. A standard reference material IPE 952 (International Plant-Analytical Exchange) from Wageningen (Netherlands) was used for quality control purposes. Crude $\mathrm{SiO}_{2}$ in shoots and roots was determined by gravimetric method. Plant samples were digested with nitric acid and filtered. The filter paper and residue were dried, calcined in a muffle furnace at $1000{ }^{\circ} \mathrm{C}$, then cooled and weighed [56].

\subsection{Calculation of the Bioaccumulation and Translocation Factor}

In order to compare metal accumulation in plants, bioaccumulation coefficients (BF) of shoots and roots were calculated by the following formulas according to Melo et al. [57]:

$$
\mathrm{BF}_{\text {shoot }}=\frac{\mathrm{Zn} \text { concentration in shoots }\left(\mathrm{mg} \mathrm{kg}^{-1}\right)}{\mathrm{Zn} \text { concentration in soil }\left(\mathrm{mg} \mathrm{kg}^{-1}\right)}
$$




$$
\mathrm{BF}_{\text {root }}=\frac{\mathrm{Zn} \text { concentration in roots }\left(\mathrm{mg} \mathrm{kg}^{-1}\right)}{\mathrm{Zn} \text { concentration in soil }\left(\mathrm{mg} \mathrm{kg}^{-1}\right)}
$$

The transfer of metals from roots to shoots was determined based on the translocation factor (TF) expressed by the formula [57]:

$$
\mathrm{TF}=\frac{\mathrm{Zn} \text { concentration in shoos }\left(\mathrm{mg} \mathrm{kg}^{-1}\right)}{\text { Zn concentration in roots }\left(\mathrm{mg} \mathrm{kg}^{-1}\right)}
$$

\subsection{Statistical Analyses}

As the results of the spring and autumn experiments were very similar to each other, it was decided to average them. All results of plant biomass and $\mathrm{Zn}$ and Si concentration were given as the means from these two experiments. ANOVA calculations were performed using the Statgraphics v 5.0 software (StatPoint Technologies, Inc., Warrenton, VA, USA). Multiple comparisons among groups were made with Tukey's honest significant difference test $(p<0.05)$.

\section{Results}

\subsection{Plants Biomass}

The dose of $600 \mathrm{mg} \mathrm{kg}^{-1} \mathrm{Zn}$ had a toxic effect on wheat and caused a 44\% decrease in shoot biomass and the same decrease in root biomass compared to a control treatment without Zn (Figure 1). Soil application of $\mathrm{Si}$ reduced considerably the negative effect of $\mathrm{Zn}$ and caused a $23-25 \%$ increase in shoot biomass and a $12-17 \%$ increase in root biomass in comparison to the $\mathrm{Zn}$ treatment without $\mathrm{Si}$.
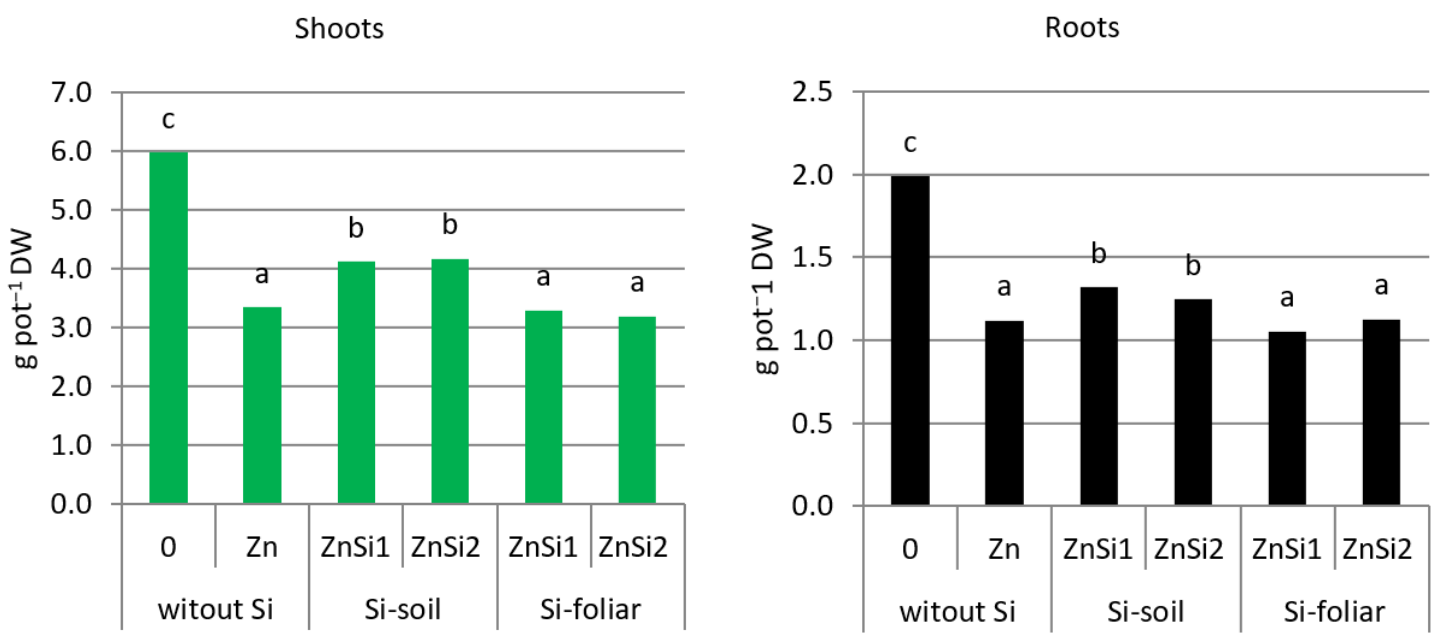

Figure 1. Biomass of wheat shoots and roots. Values marked with the same letters indicate no significant difference according to Tukey's test $(p<0.05)$.

In contrast, foliar application of Si did not reduce $\mathrm{Zn}$ toxicity to wheat. Biomass of shoots and roots from the treatments $\mathrm{ZnSi1}$-foliar $\left(2 \mathrm{mM} \mathrm{L}^{-1} \mathrm{Si}\right)$ and $\mathrm{ZnSi2}$-foliar $\left(6 \mathrm{mM} \mathrm{L}^{-1} \mathrm{Si}\right)$ was almost the same as from the treatment with only $\mathrm{Zn}$ without Si.

\subsection{Zn Concentration in Shoots and Roots}

The wheat shoots from the control treatment contained $38 \mathrm{mg} \mathrm{kg}^{-1}$, while roots $119 \mathrm{mg} \mathrm{kg}^{-1} \mathrm{Zn}$. Soil application of $600 \mathrm{mg} \mathrm{kg}^{-1} \mathrm{Zn}$ caused a 40 -fold increase in the Zn concentration in shoots and roots (Figure 2). Soil application of Si resulted in a significant reduction in $\mathrm{Zn}$ content, whereas the dose of $400 \mathrm{Si} \mathrm{mg} \mathrm{kg}{ }^{-1}$ (ZnSi2-soil) gave a considerably bigger effect than $200 \mathrm{mg} \mathrm{kg}^{-1} \mathrm{Si}$ (ZnSi1-soil). 
The concentration of $\mathrm{Zn}$ in shoots decreased by $41-56 \%$, and in roots by $24-41 \%$, respectively, to the Si dose.
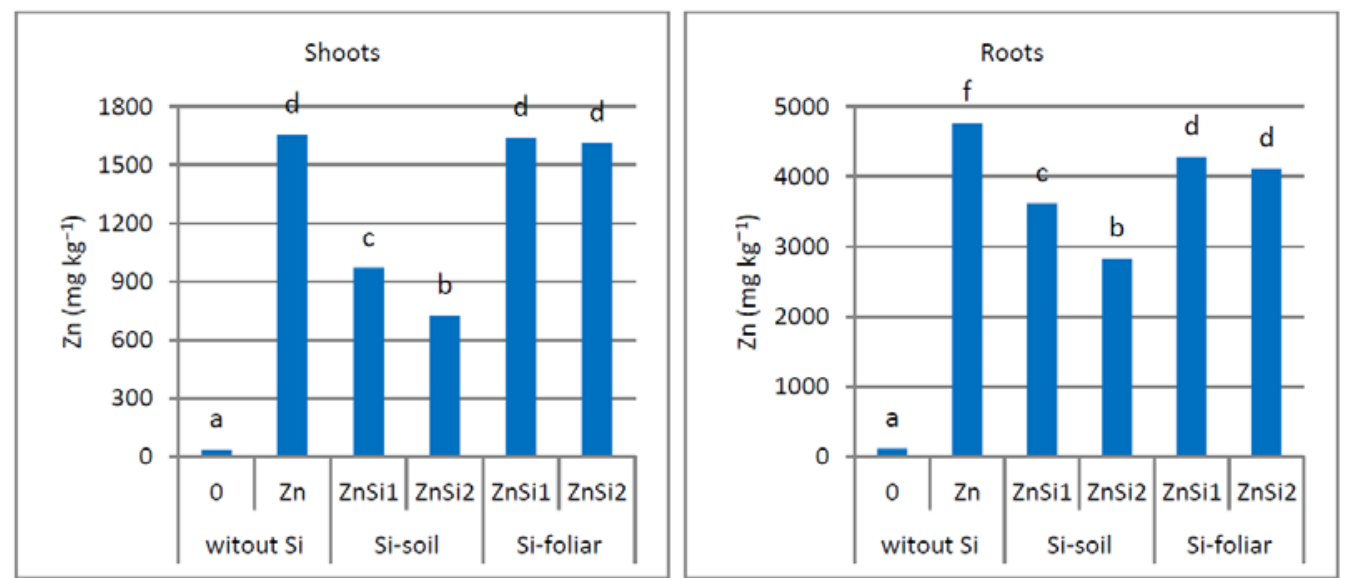

Figure 2. Zn concentration in shoots and roots of wheat. Values marked with the same letters indicate no significant difference according to Tukey's test $(p<0.05)$.

Foliar application of Si did not have such a beneficial effect on the concentration of $\mathrm{Zn}$ in plants as the soil application. Triple spraying with $2 \mathrm{mM} \mathrm{L}^{-1}$ (ZnSi1-foliar) and $6 \mathrm{mM} \mathrm{L}^{-1} \mathrm{Si}$ (ZnSi2-foliar) did not cause any changes in $\mathrm{Zn}$ in shoots and only $10-14 \%$ decrease in $\mathrm{Zn}$ in roots compared to the treatment Zn without Si.

\subsection{Si Concentration in Shoots and Roots}

The Si concentration in both treatments without $\mathrm{Si}(0$ and $\mathrm{Zn})$ was similar to each other and ranged between 2.1-2.3\% $\mathrm{SiO}_{2}$ in shoots and $11.8-12.4 \% \mathrm{SiO}_{2}$ in roots of wheat (Figure 3). Soil application of Si significantly increased Si amount in shoots. The dose of $200 \mathrm{mg} \mathrm{kg}^{-1} \mathrm{Si}$ (ZnSi1-soil) increased Si concentration by $55 \%$, while dose $400 \mathrm{mg} \mathrm{kg}^{-1} \mathrm{Si}$ (ZnSi2-soil) by $77 \%$ compared to the control. The increase in Si concentration in roots was smaller than in shoots. Only $400 \mathrm{mg} \mathrm{kg}^{-1} \mathrm{Si}$ increased Si concentration by $29 \%$, while $200 \mathrm{mg} \mathrm{kg}^{-1} \mathrm{Si}$ caused a $9 \%$, a statistically insignificant increase in $\mathrm{Si}$ concentration compared to the control treatment.
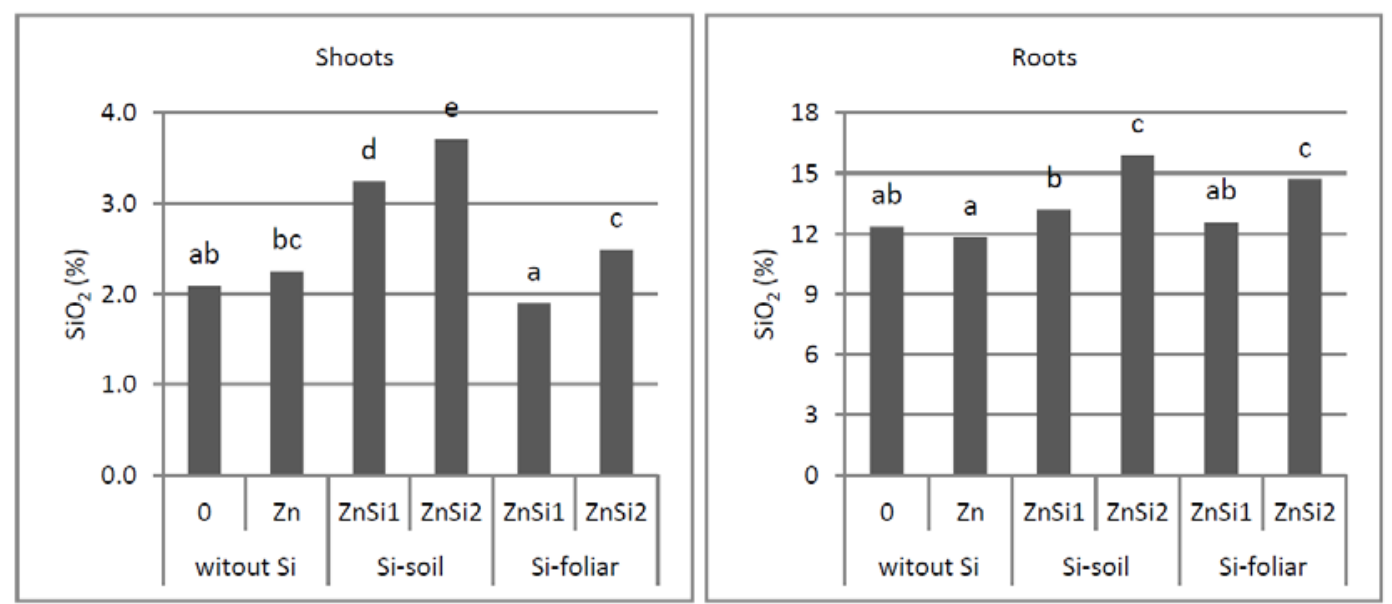

Figure 3. $\mathrm{SiO}_{2}$ concentration in shoots and roots of wheat. Values marked with the same letters indicate no significant difference according to Tukey's test $(p<0.05)$.

Foliar application of Si much less increased Si concentration in wheat plants than the soil application. Spraying with $2 \mathrm{mM} \mathrm{L}^{-1} \mathrm{Si}$ (ZnSi1-foliar) did not produce any results, while spraying 
with $6 \mathrm{mM} \mathrm{L}^{-1} \mathrm{Si}$ (ZnSi2-foliar) caused a 19\% increase in the concentration of this element both in wheat shoots and roots.

\subsection{Zn Concentration in Soil}

The soil from the control treatment contained $33 \mathrm{mg} \mathrm{kg}^{-1}$ of total $\mathrm{Zn}$ and $13 \mathrm{mg} \mathrm{kg}^{-1}$ of available $\mathrm{Zn}$, determined with Mehlich 3 method. Adding $600 \mathrm{mg} \mathrm{kg}^{-1} \mathrm{Zn}$ to the soil increased the total $\mathrm{Zn}$ in the soil to a level of $668-700 \mathrm{mg} \mathrm{kg}^{-1}$, while available $\mathrm{Zn}$ to $568-607 \mathrm{mg} \mathrm{kg}^{-1}$ (Figure 4). The Si application did not significantly affect the $\mathrm{Zn}$ content of the soil.
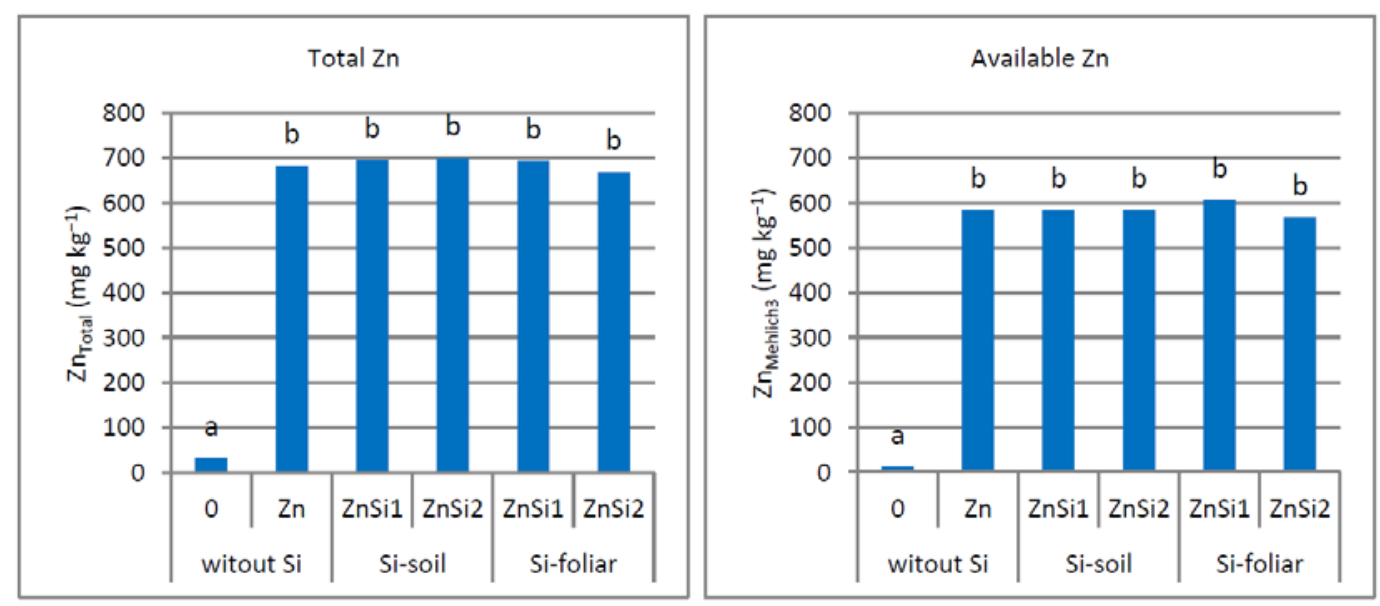

Figure 4. Zn concentration in soil. Values marked with the same letters indicate no significant difference according to Tukey's test $(p<0.05)$.

\subsection{Soil $p H$}

The initial $\mathrm{pH}$ of the soil in the control treatment was 6.5 (Figure 5). Zn application decreased $\mathrm{pH}$ to the level of 5.7-5.9 in 3 treatments: Zn, ZnSi1-foliar, and ZnS2-foliar. The soil application of Si (ZnSi1-soil and ZnSi2-soil) counteracted the $\mathrm{pH}$ decrease and kept it at a level close to the control treatment.

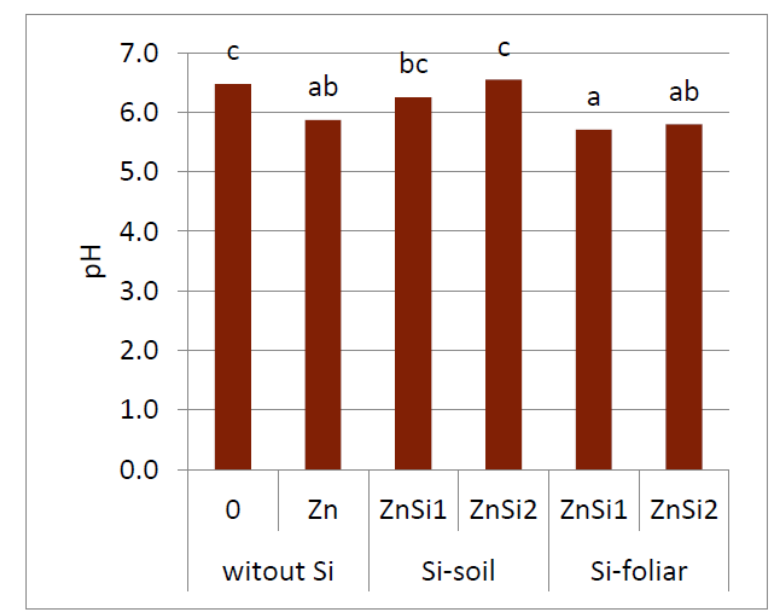

Figure 5. Soil $\mathrm{pH}$. Values marked with the same letters indicate no significant difference according to Tukey's test $(p<0.05)$.

\subsection{Zn Bioaccumulation and Translocation}

Bioaccumulation factor for shoots $\left(\mathrm{BF}_{\text {shoot }}\right)$ ranged within 1.1-2.4, while for roots $\left(\mathrm{BF}_{\text {root }}\right)$ it was much higher, fluctuating within 4.2-7.0 (Table 2). This indicates a higher accumulation of $\mathrm{Zn}$ in roots 
than in shoots. $\mathrm{BF}_{\text {shoot }}$ in $\mathrm{Zn}$-without Si treatment amounted to 2.4 and decreased to the level of 1.1-1.4 as a result of the soil $\mathrm{Si}$ application. Foliar $\mathrm{Si}$ application did not reduce the value of $\mathrm{BF}_{\text {shoot }}$, which remained at the level of 2.4. $\mathrm{BF}_{\text {root, }}$, similarly as $\mathrm{BF}_{\text {shoot }}$, being the highest in the $\mathrm{Zn}$-without $\mathrm{Si}$ treatment. In the roots, however, unlike in the shoots, both soil and foliar application of Si lowered the $\mathrm{BF}$ value. The value of $\mathrm{BF}_{\text {root }}$ fell from the level of 7.0 to 4.1-5.2 in the case of soil application and down to the level 6.2 in the case of foliar application.

Table 2. Bioaccumulation and translocation factors of $\mathrm{Zn}$.

\begin{tabular}{cccc}
\hline Treatment & $\mathbf{B F}_{\text {shoot }}$ & $\mathbf{B F}_{\text {root }}$ & $\mathbf{T F}$ \\
\hline Zn-without $\mathrm{Si}$ & 2.42 & 7.00 & 0.35 \\
\hline ZnSi1-soil & 1.39 & 5.21 & 0.27 \\
ZnSi2-soil & 1.08 & 4.08 & 0.26 \\
\hline ZnSi1-foliar & 2.35 & 6.17 & 0.38 \\
ZnSi2-foliar & 2.39 & 6.16 & 0.39 \\
\hline tion factor for shoota; $\mathrm{BF}_{\text {root }}$ - Bioaccumulation factor for roots; $\mathrm{TF}$-Translocation factor.
\end{tabular}

Translocation factor (TF), showing the ability of plants to transfer metals from the roots to the above-ground parts, was 0.35 in the $\mathrm{Zn}$-without $\mathrm{Si}$ treatment. Soil Si application decreased TF to the level of $0.26-0.27$, while foliar application increased it slightly to the level of $0.38-0.39$.

\section{Discussion}

\subsection{Plant Biomass}

In the conducted pot experiments, the addition of $600 \mathrm{mg} \mathrm{kg}^{-1} \mathrm{Zn}$ to the soil had a toxic effect on wheat, causing an approximately $40 \%$ decrease in shoot and root biomass (Figure 1). The addition of 200 and $400 \mathrm{mg} \mathrm{kg}^{-1} \mathrm{Si}$ to the soil limited the decrease in biomass, while a three-time foliar spraying with $2 \mathrm{mM} \mathrm{L}^{-1}$ and $6 \mathrm{mM} \mathrm{L}^{-1}$ did not show such effect. It can be assumed that a lower soil dose of Si ( $200 \mathrm{mg} \mathrm{kg}^{-1}$ ) was sufficient because both doses used had a similar effect. Furthermore, a bigger effect of $\mathrm{Si}$ was observed on limiting the decrease of shoot biomass (23-25\%) than of root biomass (12-17\%).

Similar results of mitigating the toxicity of $\mathrm{Zn}$ by Si were obtained by other authors, but in water culture studies, where Si was added to the nutrient solution, and not to the soil, as in our studies. In the studies of Anwaar et al. [8] the addition of 25 and $50 \mu \mathrm{M} Z n$ to the nutrient solution resulted in a significant decrease in the yield of leaves, stems and roots of young cotton plants. The addition of $\mathrm{Si}$ increased the ability of plants to cope with $\mathrm{Zn}$ excess and reduced the decrease in biomass. On the $\mathrm{Zn}+\mathrm{Si}$ treatment, the yield of leaves was by $34-76 \%$, of stems by $26-111 \%$, while of roots by $21-62 \%$ higher than in the Zn-without Si treatment. Similar results were obtained by Kaya et al. [42], where Si increased the biomass of 5 -week-old maize shoots by $42 \%$ and the root biomass by $50 \%$ compared to the Zn-treatment without Si. In the research of Song et al. [44], Si significantly mitigated the decrease in shoot and root biomass caused by an excess of $\mathrm{Zn}$ in two cultivars of rice, and this effect was, as in our research, bigger for shoots than roots. Furthermore, Gu et al. [58] showed a positive effect of Si addition on the biomass of 40-day-old rice plants subjected to $\mathrm{Zn}$ stress. This effect was bigger under a higher dose of $\mathrm{Si}$, and similarly to the study by Song et al. [44], stronger for shoots than roots. Similar results were obtained by Mehrabanjoubani et al. [43]. Shoot biomass of young rice plants was significantly higher in $100 \mu \mathrm{M} Z \mathrm{Zn}+$ Si treatment in comparison with the $100 \mu \mathrm{M}$ Zn without Si treatment, yet no significant effect of $\mathrm{Si}$ on root biomass was observed.

Bokor et al. [40] obtained completely different results for maize grown hydroponically. These authors found no beneficial effect of $\mathrm{Si}$ in alleviating the symptoms of $\mathrm{Zn}$ toxicity. Moreover, they observed a negative effect of $\mathrm{Si}$ on the biomass of roots and shoots of 10-day-old corn seedlings subjected to $\mathrm{Zn}$ stress. The dose of $182 \mu \mathrm{M} \mathrm{Zn}$ caused a 38\% decrease in shoot biomass as compared 
to the control without $\mathrm{Zn}$. The applied doses of Si aggravated this decrease, causing the largest $54 \%$ decrease at the dose of $5.0 \mathrm{mM}$ Si.

\subsection{Zn Concentration in Shoots and Roots}

Excess $\mathrm{Zn}$ in the substrate causes excessive concentration of this element in plants, which can interfere with various metabolic processes. The application of $S i$ generally leads to a reduction in the uptake and accumulation of $\mathrm{Zn}$. In our research, the application of $600 \mathrm{mg} \mathrm{kg}^{-1} \mathrm{Zn}$ to the soil caused a very large, about 40 -fold $\mathrm{Zn}$ increase in wheat shoots and roots (Figure 2). Soil application of $\mathrm{Si}$ reduced this concentration by $41-56 \%$ in shoots and by $24-41 \%$ in roots (Figure 1). Although the dose of $400 \mathrm{mg} \mathrm{kg}^{-1} \mathrm{Si}$ reduced the concentration of $\mathrm{Zn}$ much more than $200 \mathrm{mg} \mathrm{kg}^{-1} \mathrm{Si}$, this fact did not affect the plant biomass, which was similar for both Si doses. The concentration of $\mathrm{Zn}$ in wheat tissues was significantly less influenced by the foliar application than the soil application of $\mathrm{Si}$. A three-time spraying did not reduce $\mathrm{Zn}$ in shoots and caused only a 10-14\% reduction in roots compared to the $\mathrm{Zn}$ - without $\mathrm{Si}$ treatment. It can be assumed that the lack of $\mathrm{Zn}$ decrease in shoots and only a small $\mathrm{Zn}$ decrease in roots caused the lack of beneficial effect of foliar application of Si on wheat biomass.

It is not possible for us to compare the effects of soil and foliar application of $\mathrm{Si}$ on the reduction of $\mathrm{Zn}$ in plant tissues with the results of other authors because there are no similar studies. The studies of other authors concern water cultures, where $\mathrm{Si}$ is applied directly to nutrient solution contaminated with $\mathrm{Zn}$. Nevertheless, these authors prove the reduction of $\mathrm{Zn}$ in plant tissues under the influence of $\mathrm{Si}$ addition to the nutrient solution. In the studies of Anwaara et al. [8], the addition of Si resulted in a significant reduction of $\mathrm{Zn}$ in leaves, stems and roots of young cotton plants exposed to stress caused by excess Zn. Furthermore, Mehrabanjoubani et al. [43], Kaya et al. [42] and Gu et al. [58] observed a significant reduction of $\mathrm{Zn}$ concentration in the shoots and roots of rice seedlings as a result of the addition of $\mathrm{Si}$ under conditions of excess $\mathrm{Zn}$ in the nutrient solution Moreover, as in our research, $\mathrm{Gu}$ et al. [58] found that the higher dose of $\mathrm{Si}(1.8 \mathrm{mM})$ was more effective than the lower one $(0.5 \mathrm{mM})$, causing a greater decrease in $\mathrm{Zn}$ content in plants. Bokor et al. [40] also proved higher efficacy of high doses than low doses of Si. In the study with 10-day maize seedlings, they showed that addition of $5 \mathrm{mM} \mathrm{Si}$ caused almost twice as much decrease of $\mathrm{Zn}$ concentration in roots as the addition of $1 \mathrm{mM} \mathrm{Si}$.

Song et al. [44] achieved different results. In the study with two cultivars of rice, they observed a significant increase in $\mathrm{Zn}$ concentration in the shoots and roots of 14-day-old seedlings growing on $\mathrm{Zn}$-contaminated nutrient solution. The addition of $\mathrm{Si}$ to the nutrient solution resulted in a continued increase in $\mathrm{Zn}$ concentration in roots and a significant $\mathrm{Zn}$ decrease in shoots. These results were confirmed by later studies by the same authors [9]. They suggest the influence of Si on the accumulation of $\mathrm{Zn}$ in roots and limiting its transport to shoots.

\subsection{Si Concentration in Shoots and Roots}

The soil doses of Si used in our experiments were $200 \mathrm{mg} \mathrm{kg}^{-1}$ (Si1-soil) and $400 \mathrm{mg} \mathrm{kg}^{-1}$ (Si2-soil), while foliar doses were $2 \mathrm{mM} \mathrm{L}^{-1}$ (Si1-foliar) and $6 \mathrm{mM} \mathrm{L}^{-1}$ (Si2-foliar). Similar soil doses of Si in pot tests were used by Habibi [59], Liang et al. [28], Naaem et al. [29], Vieira da Cunha et al. [45] and Zhang et al. [35]. Similar to ours, Si concentrations for foliar spraying were used by Shahid et al. [60], Bukhari et al. [22], Kamenidou et al. [61], and Pilon et al. [62].

Our results showed that the $\mathrm{Si}$ concentration was several times higher in wheat roots than in the shoots. This applied to all treatments - control without $\mathrm{Zn}$ and $\mathrm{Si}, \mathrm{Zn}$ without $\mathrm{Si}$, and $\mathrm{Zn}+\mathrm{Si}$ (Figure 3). Different results for 10-day hydroponically grown maize seedlings were presented by Bokor et al. [40]. In their study, there was more $\mathrm{Si}$ in shoots than in roots in the control treatment and at lower Si doses (1 and $2.5 \mathrm{mM})$. However, under the highest dose of $\mathrm{Si}(5 \mathrm{mM})$, this proportion changed, and there was more Si in the roots than in the shoots. This applied both to Si without $\mathrm{Zn}$ treatments, and to $\mathrm{Si}+\mathrm{Zn}$ treatments.

The results of our experiments showed that both soil and foliar application of Si significantly increased its concentration in wheat shoots and roots, yet soil application was more effective (Figure 3). 
Moreover, in both ways of application, the Si2 doses caused a higher increase in $\mathrm{Si}$ in plant tissues compared to the Si1 doses. Soil application of $400 \mathrm{mg} \mathrm{kg}^{-1} \mathrm{Si}$ (ZnSi2-soil treatment) increased its concentration by $77 \%$ in shoots and by $29 \%$ in roots, while application of $6 \mathrm{mM} \mathrm{L}^{-1}$ (ZnSi2-foliar treatment) increased $\mathrm{Si}$ in both shoots and roots by only $19 \%$.

On the basis of the plant biomass and $\mathrm{Zn}$ and Si concentration in wheat tissues, it can be assumed that the soil dose of $200 \mathrm{mg} \mathrm{kg}^{-1} \mathrm{Si}$ was sufficient. Although the dose of $400 \mathrm{mg} \mathrm{kg}^{-1} \mathrm{Si}$ increased the Si content and decreased the $\mathrm{Zn}$ content in wheat tissues more than the dose of $200 \mathrm{mg} \mathrm{kg}^{-1} \mathrm{Si}$, but this fact did not affect the plant biomass. (Figures 1-3). Different conclusions should be drawn about the foliar Si doses. Due to the fact that in most cases, only the S2-foliar concentration worked, it can be assumed that a concentration higher than $6 \mathrm{mM} \mathrm{L}^{-1}$ would be more effective.

\subsection{Zn Concertation in Soil}

Several authors report that the application of $\mathrm{Si}$ in the form of silicates to nutrient solution or to the soil contaminated with metals, can lead to the immobilization of metals, and thus reduce the availability of metals for plants. Bokor et al. [40] report on precipitation of insoluble $\mathrm{Zn}_{2} \mathrm{SiO}_{4}$ under the application of $\mathrm{Si}$ and $\mathrm{Zn}$ to the nutrient solution in a water culture experiment. Furthermore, Liang et al. [28] found Cd immobilization in the soil in result of the soil application of $400 \mathrm{mg} \mathrm{kg}^{-1} \mathrm{Si}$ in the form of $\mathrm{Na}_{2} \mathrm{SiO}_{3}$ in a pot experiment. This dose caused a decrease in available Cd in soil, determined in $\mathrm{CaCl}_{2}$, compared to the treatment without $\mathrm{Si}$. Moreover, these authors observed less exchangeable $\mathrm{Cd}$ and more $\mathrm{Cd}$ in forms specifically adsorbed or bounded with Fe and Mn oxides in the soil in the treatments with $\mathrm{Si}$ application compared to the treatments without $\mathrm{Si}$.

In contrast, in our experiments, soil applications of 200 and $400 \mathrm{mg} \mathrm{kg}^{-1} \mathrm{Si}$ did not affect the concentration of available $\mathrm{Zn}$ in soil, determined by Mehlich 3 (Figure 4). Perhaps such an effect would have been revealed by using a weaker extractant than Mehlich 3.

\subsection{Zn Transfer from Roots to Shoots}

Soil Si application decreased the $\mathrm{Zn}$ transfer from roots to shoots by 23-27\% (Table 2). This protected the photosynthetic apparatus, which was probably the reason for limiting the yield decrease. The foliar application did not reduce the transfer from roots to shoots, and there was even a tendency to increase it by $9-11 \%$. This is probably the reason for the lack of the beneficial effect in biomass of foliar Si application.

Other authors also report the role of $\mathrm{Si}$ in limiting the transfer of heavy metals from the roots to the aerial parts [23,29,32]. The studies of Shi et al. [31] confirmed the reduction of metal translocation from roots to shoots by $\mathrm{Si}$. These authors, using an electron microscope, showed a strong deposition of silicon in the vicinity of the root endoderm of young rice seedlings. The physical barrier created in this way, can reduce the porosity of the cell walls of the inner root tissues, thus blocking Cd transport through the apoplast. However, Bokor et al. [40] demonstrated that the reduced Zn translocation from roots to shoots caused by $\mathrm{Si}$ did not reduce the toxicity of $\mathrm{Zn}$ in young maize plants under aquatic culture conditions. These authors suggest that caution should be taken when generalizing and formulating conclusions about the alleviating effects of Si on metal toxicity.

\subsection{The Joint Effect of Si and $p H$ Changes in Alleviating Zn Toxicity}

Application $\mathrm{Zn}$ to the soil in the form of zinc sulfate resulted in a decrease in $\mathrm{pH}$ by 0.6 units compared to the control treatment (Figure 5). It should be assumed that the decrease in $\mathrm{pH}$ increased the $\mathrm{Zn}$ bioavailability, and thus contributed to its higher toxicity. The increase in availability of $\mathrm{Zn}$ for plants due to the decrease in $\mathrm{pH}$ is a well-known phenomenon [63]. Soil application of $\mathrm{Si}$ in the form of sodium silicate counteracted the decrease in $\mathrm{pH}$, which undoubtedly contributed to limiting $\mathrm{Zn}$ uptake on $\mathrm{ZnSi1}$-soil and $\mathrm{ZnSi2}$-soil treatments. The fact that the $\mathrm{pH}$ in treatments with foliar $\mathrm{Si}$ application was similar to that in the $\mathrm{Zn}$-without Si treatment confirms the influence of sodium silicate introduced into the soil on the increase in soil $\mathrm{pH}$. The impact of $\mathrm{Na}_{2} \mathrm{SiO}_{3}$ to the increase of soil $\mathrm{pH}$ is 
reported also by other authors $[28,35]$. It can therefore be assumed that the beneficial effect of reducing the toxicity of $\mathrm{Zn}$ in the treatments with soil application of $\mathrm{Si}$ was caused not only by the effect of silicon, but also by an increase in $\mathrm{pH}$. The evidence that it was not only the effect of $\mathrm{pH}$, but also the effect of $\mathrm{Si}$, can be a significant increase in $\mathrm{Si}$ concentration in wheat shoots and roots in the treatments ZnSi1-soil and ZnSi2-soil (Figure 3). Such an increase also occurred in the ZnSi2-foliar treatment, but it was considerably lower than in the case of soil application and did not manage to compensate for the decrease in $\mathrm{pH}$ in this treatment. Taking into account that the lower concentration of $\mathrm{Si}\left(2 \mathrm{mM} \mathrm{L}^{-1}\right)$ did not cause the increase of this element in plants, it can be assumed that a larger foliar supply of Si than in the treatment $\mathrm{ZnSi2}$-foliar $\left(6 \mathrm{mM} \mathrm{L}^{-1}\right)$ could alleviate the toxicity of $\mathrm{Zn}$.

Changes in soil $\mathrm{pH}$ and $\mathrm{Si}$ concentration in plants due to application $\mathrm{ZnSO}_{4}$ and $\mathrm{Na}_{2} \mathrm{SiO}_{3}$ observed in our experiments, and their effect on the reduction of $\mathrm{Zn}$ toxicity to plants, are difficult to compare with the results of other authors. Other studies on alleviating $\mathrm{Zn}$ toxicity by $\mathrm{Si}$ were carried out in water cultures where $\mathrm{Zn}$ and $\mathrm{Si}$ were added to the nutrient solution $[8,9,40,42-44,58,64]$. There is a lack of research on plants growing on $\mathrm{Zn}$-contaminated soil, where Si would be applied into the soil or to the leaves. However, there are studies describing the effect of $\mathrm{Si}$ on the alleviation of $\mathrm{Cd}$ toxicity. Liang et al. [28], similarly to us, showed an increase in $\mathrm{pH}$ due to application of $\mathrm{Si}$ in the form of $\mathrm{Na}_{2} \mathrm{SiO}_{3}$ to the soil contaminated with $\mathrm{Cd}$. In their conclusion, however, they state that $\mathrm{Si}$ itself can effectively alleviate the $\mathrm{Cd}$ toxicity in maize. The alleviative effect of $\mathrm{Si}$ on Cd toxicity can be attributed not only to $\mathrm{Cd}$ immobilization in soil and its low phytoavailability resulting from $\mathrm{pH}$ rise in the Si-amended soil, but also to the Si-mediated Cd detoxification in plants.

\section{Conclusions}

Soil Si application alleviated $\mathrm{Zn}$ toxicity for young wheat plants, while foliar application did not cause beneficial effects in the form of reducing the decrease of biomass. Soil application of $\mathrm{Na}_{2} \mathrm{SiO}_{3}$ increased the Si concentration and decreased the Zn concentration in the shoots and roots, as well as limited the translocation of $\mathrm{Zn}$ from the roots to the shoots compared to the $\mathrm{Zn}$-without $\mathrm{Si}$ treatment. Both soil doses of $\mathrm{Si}$ (200 and $400 \mathrm{mg} \mathrm{kg}^{-1}$ ) gave a similar effect, which allows to presume that a lower dose was sufficient. It can be assumed that the reduction of $\mathrm{Zn}$ toxicity to plants by the soil applied sodium silicate was caused both by a slight increase in soil $\mathrm{pH}$ and the uptake of Si by plants. The addition of $\mathrm{Na}_{2} \mathrm{SiO}_{3}$ to the soil increased the soil $\mathrm{pH}$ by $0.4-0.7$ units.

The foliar application of $\mathrm{Na}_{2} \mathrm{SiO}_{3}$ reduced the $\mathrm{Zn}$ concentration in the roots less than the soil application and did not reduce $\mathrm{Zn}$ concentration in the shoots. The foliar application did not limit the translation of $\mathrm{Zn}$ from roots to shoots. Only a higher dose of $\mathrm{Si}\left(6 \mathrm{mM} \mathrm{L}^{-1}\right)$ increased its concentration in shoots and roots, while a lower dose $\left(2 \mathrm{mM} \mathrm{L}^{-1}\right)$ did not give this effect. This suggests that the supply of $\mathrm{Si}$ in a triple spray of sodium silicate at a concentration of $2 \mathrm{mM} \mathrm{L}^{-1}$ was too low. It can be assumed that a higher concentration of $\mathrm{Si}$ or more sprayings would give better results.

Author Contributions: A.Z. performed pot experiments, analysed the data, performed statistical analysis and wrote the paper, J.K. conceived and designed the experiments, interpreted the data, wrote the paper; U.S.-C. revised the manuscript, consulted chemical analysis. All authors have read and agreed to the published version of the manuscript.

Funding: This research was supported by Polish Ministry of Agriculture and Rural Development under 2.35 Scientific Research Program of Institute of Soil Science and Plant Cultivation in Pulawy.

Conflicts of Interest: The authors declare no conflict of interest.

\section{References}

1. Chaney, R.Á. Zinc phytotoxicity. In Zinc in Soils and Plants; Springer: Dordrecht, The Netherlands, 1993; pp. 135-150.

2. Ciarkowska, K.; Gambus, F.; Antonkiewicz, J.; Koliopoulos, T. Polycyclic aromatic hydrocarbon and heavy metal contents in the urban soils in southern Poland. Chemosphere 2019, 229, 214-226. [CrossRef] [PubMed] 
3. Li, P.; Lin, C.; Cheng, H.; Duan, X.; Lei, K. Contamination and health risks of soil heavy metals around a lead/zinc smelter in southwestern China. Ecotoxicol. Environ. Saf. 2015, 113, 391-399. [CrossRef] [PubMed]

4. Noulas, C.; Tziouvalekas, M.; Karyotis, T. Zinc in soils, water and food crops. J. Trace Elem. Med. Biol. 2018, 49, 252-260. [CrossRef] [PubMed]

5. Maliszewska-Kordybach, B.; Smreczak, B.; Klimkowicz-Pawlas, A. Zagrożenie zanieczyszczeniami chemicznymi gleb na obszarach rolniczych w Polsce w świetle badan IUNG-PIB w Puławach (Threat of chemical contamination in agricultural areas in Poland in the context of research of IUNG-PIB in Pulawy). Studia Rap. IUNG-PIB 2013, 35, 97-118.

6. Nagajyoti, P.C.; Lee, K.D.; Sreekanth, T.V.M. Heavy metals, occurrence and toxicity for plants: A review. Environ. Chem. Lett. 2010, 8, 199-216. [CrossRef]

7. Rout, G.R.; Das, P. Effect of metal toxicity on plant growth and metabolism: I. Zinc. In Sustainable Agriculture; Springer: Dordrecht, The Netherlands, 2009; pp. 873-884.

8. Anwaar, S.A.; Ali, S.; Ali, S.; Ishaque, W.; Farid, M.; Farooq, M.A.; Najeeb, U.; Abbas, F.; Sharif, M. Silicon (Si) alleviates cotton (Gossypium hirsutum $\mathrm{L}$.) from zinc $(\mathrm{Zn})$ toxicity stress by limiting $\mathrm{Zn}$ uptake and oxidative damage. Environ. Sci. Pollut. Res. 2015, 22, 3441-3450. [CrossRef]

9. Song, A.; Li, P.; Fan, F.; Li, Z.; Liang, Y. The effect of silicon on photosynthesis and expression of its relevant genes in rice (Oryza sativa L.) under high-zinc stress. PLoS ONE 2014, 9, e113782. [CrossRef]

10. Epstein, E. Silicon. Annu. Rev. Plant Biol. 1999, 50, 641-664. [CrossRef]

11. Epstein, E. The anomaly of silicon in plant biology. Proc. Natl. Acad. Sci. USA 1994, 91, 11-17. [CrossRef]

12. Epstein, E.; Bloom, A.J. Mineral Nutrition of Plants: Principles and Perspectives, 2nd ed.; Sinauer: Sunderland, MA, USA, 2005.

13. Liang, Y.; Sun, W.; Zhu, Y.G.; Christie, P. Mechanisms of silicon-mediated alleviation of abiotic stresses in higher plants: A review. Environ. Pollut. 2007, 147, 422-428. [CrossRef] [PubMed]

14. Farooq, M.A.; Dietz, K.J. Silicon as versatile player in plant and human biology: Overlooked and poorly understood. Front. Plant Sci. 2015, 6, 994. [CrossRef]

15. Guével, M.H.; Menzies, J.G.; Bélanger, R.R. Effect of root and foliar applications of soluble silicon on powdery mildew control and growth of wheat plants. Eur. J. Plant Pathol. 2007, 119, 429-436. [CrossRef]

16. Ma, J.F.; Yamaji, N. Silicon uptake and accumulation in higher plants. Trends Plant Sci. 2006, 11, $392-397$. [CrossRef]

17. Diwan, S.B.; Saiyad, M.; Dhruve, J.J. Effect of foliar application of silicon on growth and development of okra fruit. Int. J. Pharmacogn. Phytochem. Res. 2019, 8, 1552-1558.

18. Othman, A.; Ayed, S.; Bezzin, O.; Farooq, M.; Ayed-Slama, O.; Slim-Amara, H.; Younes, M.B. Effect of Silicon Supply Methods on Durum Wheat (Triticum durum Desf.) Response to Drought Stress. Silicon 2020. [CrossRef]

19. Sattar, A.; Cheema, M.A.; Sher, A.; Ijaz, M.; Wasaya, A.; Yasir, T.A.; Abbas, T.; Hussain, M. Foliar Applied Silicon Improves Water Relations, Stay Green and Enzymatic Antioxidants Activity in Late Sown Wheat. Silicon 2020, 12, 223-230. [CrossRef]

20. Guntzer, F.; Keller, C.; Meunier, J.D. Benefits of plant silicon for crops: A review. Agron. Sustain. Dev. 2012, 32, 201-213. [CrossRef]

21. Ma, J.F.; Mitani, N.; Nagao, S.; Konishi, S.; Tamai, K.; Iwashita, T.; Yano, M. Characterization of the silicon uptake system and molecular mapping of the silicon transporter gene in rice. Plant. Physiol. 2004, 136, 3284-3289. [CrossRef]

22. Bukhari, M.A.; Ashraf, M.Y.; Ahmad, R.; Waraich, E.A.; Hameed, M. Improving drought tolerance potential in wheat (Triticum aestivum L.) through exogenous silicon supply. Pak. J. Bot. 2015, 47, 1641-1648.

23. Rizwan, M.; Ali, S.; Ibrahim, M.; Farid, M.; Adrees, M.; Bharwana, S.A.; Zia-ur-Rehman, M.; Qayyum, M.F.; Abbas, F. Mechanisms of silicon-mediated alleviation of drought and salt stress in plants: A review. Environ. Sci. Pollut. Res. 2015, 22, 15416-15431. [CrossRef] [PubMed]

24. Sienkiewicz-Cholewa, U.; Sumisławska, J.; Sacała, E.; Dziagwa-Becker, M.; Kieloch, R. Influence of silicon on spring wheat seedlings under salt stress. Acta Physiol. Plant. 2018, 40, 54. [CrossRef]

25. Zhu, Y.X.; Gong, H.J.; Yin, J.L. Role of silicon in mediating salt tolerance in plants: A review. Plants 2019, 8, 147. [CrossRef]

26. Sakr, N. Silicon control of bacterial and viral diseases in plants. J. Plant Prot. Res. 2016, 56, 331-336. [CrossRef] 
27. Wu, J.W.; Shi, Y.; Zhu, Y.X.; Wang, Y.C.; Gong, H.J. Mechanisms of enhanced heavy metal tolerance in plants by silicon: A review. Pedosphere 2013, 23, 815-825. [CrossRef]

28. Liang, Y.; Wong, J.W.C.; Wei, L. Silicon-mediated enhancement of cadmium tolerance in maize (Zea mays L.) grown in cadmium contaminated soil. Chemosphere 2005, 58, 475-483. [CrossRef]

29. Naeem, A.; Ghafoor, A.; Farooq, M. Suppression of cadmium concentration in wheat grains by silicon is related to its application rate and cadmium accumulating abilities of cultivars. J. Sci. Food Agric. 2015, 95, 2467-2472. [CrossRef] [PubMed]

30. Rizwan, M.; Meunier, J.D.; Miche, H.; Keller, C. Effect of silicon on reducing cadmium toxicity in durum wheat (Triticum turgidum L. cv. Claudio W.) grown in a soil with aged contamination. J. Hazard. Mater. 2012, 209, 326-334. [CrossRef]

31. Shi, X.; Zhang, C.; Wang, H.; Zhang, F. Effect of Si on the distribution of Cd in rice seedlings. Plant Soil. 2005, 272, 53-60. [CrossRef]

32. Song, A.; Li, Z.; Zhang, J.; Xue, G.; Fan, F.; Liang, Y. Silicon-enhanced resistance to cadmium toxicity in Brassica chinensis L. is attributed to Si-suppressed cadmium uptake and transport and Si-enhanced antioxidant defense capacity. J. Hazard. Mater. 2009, 172, 74-83. [CrossRef]

33. Zhao, Y.; Liu, M.; Guo, L.; Yang, D.; He, N.; Ying, B.; Wang, Y. Influence of silicon on cadmium availability and cadmium uptake by rice in acid and alkaline paddy soils. J. Soils Sediments 2020, 20, 2343-2353. [CrossRef]

34. Ali, S.; Farooq, M.A.; Yasmeen, T.; Hussain, S.; Arif, M.S.; Abbas, F.; Bharwana, S.A.; Zhang, G. The influence of silicon on barley growth, photosynthesis and ultra-structure under chromium stress. Ecotoxicol. Environ. Saf. 2013, 89, 66-72. [CrossRef]

35. Ding, X.; Zhang, S.; Li, S.; Liao, X.; Wang, R. Silicon Mediated the Detoxification of Cr on Pakchoi (Brassica Chinensis L.) in Cr-contaminated Soil. Procedia Environ. Sci. 2013, 18, 58-67. [CrossRef]

36. Guo, W.; Hou, Y.L.; Wang, S.G.; Zhu, Y.G. Effect of silicate on the growth and arsenate uptake by rice (Oryza sativa L.) seedlings in solution culture. Plant Soil. 2005, 272, 173-181. [CrossRef]

37. Marmiroli, M.; Pigoni, V.; Savo-Sardaro, M.L.; Marmiroli, N. The effect of silicon on the uptake and translocation of arsenic in tomato (Solanum lycopersicum L.). Environ. Exp. Bot. 2014, 99, 9-17. [CrossRef]

38. Ali, S.; Rizwan, M.; Ullah, N.; Bharwana, S.A.; Waseem, M.; Farooq, M.A.; Abbasi, G.H.; Farid, M. Physiological and biochemical mechanisms of silicon-induced copper stress tolerance in cotton (Gossypium hirsutum L.). Acta Physiol. Plant. 2016, 38, 262. [CrossRef]

39. Collin, B.; Doelsch, E.; Keller, C.; Cazevieille, P.; Tella, M.; Chaurand, P.; Panfili, F.; Hazemann, J.L.; Meunier, J.D. Evidence of sulfur-bound reduced copper in bamboo exposed to high silicon and copper concentrations. Environ. Pollut. 2014, 187, 22-30. [CrossRef]

40. Bokor, B.; Vaculík, M.; Slováková, L'.; Masarovič, D.; Lux, A. Silicon does not always mitigate zinc toxicity in maize. Acta Physiol Plant. 2014, 36, 733-743. [CrossRef]

41. Gu, H.H.; Qiu, H.; Tian, T.; Zhan, S.S.; Chaney, R.L.; Wang, S.Z.; Tang, Y.T.; Morel, J.L.; Qiu, R.L. Mitigation effects of silicon rich amendments on heavy metal accumulation in rice (Oryza sativa L.) planted on multi-metal contaminated acidic soil. Chemosphere 2011, 83, 1234-1240. [CrossRef]

42. Kaya, C.; Tuna, A.L.; Sonmez, O.; Ince, F.; Higgs, D. Mitigation effects of silicon on maize plants grown at high zinc. J. Plant Nutr. 2009, 32, 1788-1798. [CrossRef]

43. Mehrabanjoubani, P.; Abdolzadeh, A.; Sadeghipour, H.R.; Aghdasi, M. Impacts of silicon nutrition on growth and nutrient status of rice plants grown under varying zinc regimes. Theor. Exp. Plant Physiol. 2015, 27, 19-29. [CrossRef]

44. Song, A.; Li, P.; Li, Z.; Fan, F.; Nikolic, M.; Liang, Y. The alleviation of zinc toxicity by silicon is related to zinc transport and antioxidative reactions in rice. Plant Soil. 2011, 344, 319-333. [CrossRef]

45. Vieira da Cunha, K.; Williams Araújo do Nascimento, C.; José da Silva, A. Silicon alleviates the toxicity of cadmium and zinc for maize (Zea mays L.) grown on a contaminated soil. J. Plant. Nutr. Soil Sci. 2008, 171, 849-853. [CrossRef]

46. Polish Committee for Standardization. PN-R-04033:1998. Soil and Mineral Soil Materials: Particle Size Distribution on Soil Classes; Polish Committee for Standardization: Warsaw, Poland, 1998. (In Polish)

47. International Standardization Organization. ISO 10390:2005. Soil Quality: Determination of pH; International Standardization Organization: Geneva, Switzerland, 2005.

48. Polish Committee for Standardization. PN-ISO-14235:2003. Soil Quality: Determination of Organic Carbon in Soil by Sulfochromic Oxidation; Polish Committee for Standardization: Warsaw, Poland, 2003. (In Polish) 
49. Polish Committee for Standardization. PN-R-04022:1996. Agrochemical Soil Analyse: Determination of Available Potassium Content in Mineral Soils; Polish Committee for Standardization: Warsaw, Poland, 1996. (In Polish)

50. Polish Committee for Standardization. PN-R-04020:1994. Agrochemical Soil Analyse: Determination of Available Magnesium Content in Mineral Soils; Polish Committee for Standardization: Warsaw, Poland, 1994. (In Polish)

51. International Standardization Organization. ISO 11466:1995. Soil Quality: Extraction of Trace Elements Soluble in Aqua Regia; International Standardization Organization: Geneva, Switzerland, 1995.

52. Korzeniowska, J.; Stanisławska-Glubiak, E. Comparison of $1 \mathrm{M} \mathrm{HCl}$ and Mehlich 3 for assessment of the micronutrient status of polish soils in the context of winter wheat nutritional demands. Commun. Soil Sci. Plant Anal. 2015, 46, 1263-1277. [CrossRef]

53. Korzeniowska, J.; Stanislawska-Glubiak, E.; Lipinski, W. Development of the limit values of micronutrient deficiency in soil determined using Mehlich 3 extractant for Polish soil conditions. Part I. Wheat. Soil Sci. Annu. 2019, 70, 314-323. [CrossRef]

54. Mehlich, A. Mehlich 3 soil test extractant: A modification of Mehlich 2 extractant. Commun. Soil Sci. Plant Anal. 1984, 15, 1409-1416. [CrossRef]

55. Polish Committee for Standardization. PN-R-04014:1991. Agrochemical Plant Analyse. Methods of Mineralization of Plant Material for Determination Macro- and Microelements; Polish Committee for Standardization: Warsaw, Poland, 1991. (In Polish)

56. Yoshida, S.; Forno, D.A.; Cock, J.H.; Gomez, K.A. Laboratory Manual for Physiological Studies of Rice, 3rd ed.; Intemational Rice Research Institute: Los Banos, Laguna, Philippines, 1976.

57. Melo, E.E.C.; Costa, E.T.S.; Guilherme, L.R.G.; Faquin, V.; Nascimento, C.W.A. Accumulation of arsenic and nutrients by castor bean plants grown on an As-enriched nutrient solution. J. Hazard. Mater. 2009, 168, 479-483. [CrossRef]

58. Gu, H.H.; Zhan, S.S.; Wang, S.Z.; Tang, Y.T.; Chaney, R.L.; Fang, X.H. Silicon-mediated amelioration of zinc toxicity in rice (Oryza sativa L.) seedlings. Plant Soil. 2012, 350, 193-204. [CrossRef]

59. Habibi, G. Silicon supplementation improves drought tolerance in canola plants. Russ. J. Plant Physiol. 2014, 61, 784-791. [CrossRef]

60. Shahid, M.A.; Balal, R.M.; Pervez, M.A.; Abbas, T.; AQUEEL, M.A.; Javaid, M.M.; Garcia-Sanchez, F. Foliar spray of phyto-extracts supplemented with silicon: An efficacious strategy to alleviate the salinity-induced deleterious effects in pea (Pisum sativum L.). Turk. J. Bot. 2015, 39, 408-419. [CrossRef]

61. Kamenidou, S.; Cavins, T.J.; Marek, S. Silicon supplements affect floricultural quality traits and elemental nutrient concentrations of greenhouse produced gerbera. Sci. Hortic. 2010, 123, 390-394. [CrossRef]

62. Pilon, C.; Soratto, R.P.; Moreno, L.A. Effects of soil and foliar application of soluble silicon on mineral nutrition, gas exchange, and growth of potato plants. Crop. Sci. 2013, 53, 1605-1614. [CrossRef]

63. Kabata-Pendias, A.; Mukherjee, A.B. Trace Elements from Soil to Human; Springer Science \& Business Media: Berlin, Germany, 2007.

64. Masarovič, D.; Slováková, L'.; Bokor, B.; Bujdoš, M.; Lux, A. Effect of silicon application on Sorghum bicolor exposed to toxic concentration of zinc. Biologia 2012, 67, 706-712. [CrossRef]

Publisher's Note: MDPI stays neutral with regard to jurisdictional claims in published maps and institutional affiliations.

(C) 2020 by the authors. Licensee MDPI, Basel, Switzerland. This article is an open access article distributed under the terms and conditions of the Creative Commons Attribution (CC BY) license (http://creativecommons.org/licenses/by/4.0/). 